\title{
SURINAME \\ EN HET WERELDBEVOLKINGSVRAAGSTUK
}

Bij het begin van onze jaartelling bedroeg het totaal aantal mensen op de gehele wereld ongeveer 250 millioen. Na vele schommelingen is dit aantal in de r 7 e eeuw gestegen tot 500 millioen. Omstreeks I830 wordt de Iooo millioen overschreden, honderd jaar later is dit getal reeds verdubbeld en na 30 jaar, in I96o, zijn wij reeds zeer dichtbij de 3000 millioen zielen. Of om het anders uit te drukken: bedroeg het verdubbelingsgetal eerst I70o jaar, het is daarna snel gedaald tot roo en nu zelfs reeds tot 40 jaar.

Over de oorzaak zijn alle deskundigen het eens: bij een vrijwel gelijk blijvend geboortecijfer een enorm sterk gedaald sterftecijfer. En aangezien juist in vele onderontwikkelde gebieden deze daling van het sterftecijfer het sterkst is, spreekt het ook vanzelf, dat juist in deze onderontwikkelde gebieden de bevolkingsexplosie het hevigst is.

Maar er is een ander soort begrenzing, welke een veel duidelijker limiet stelt. Zelfs al vermindert het verdubbelingscijfer van 40 jaar niet verder, dan nog zal over 600 jaar - en wat betekenen 600 jaar in de geschiedenis der mensheid - het aantal mensen op aarde zijn gestegen van 3000 millioen tot ruim $30.000 \times$ zoveel, Ioo millioen $\times$ millioen, of roo maal ro tot de rze macht. De oppervlakte van alle werelddelen op het aardoppervlak bedraagt I50 millioen $\mathrm{km}^{2}$ of ${ }^{50}$ maal ro tot de I2e macht vierkante meters, m.a.w. over 600 jaar is er I,5 vierkante meter beschikbaar per mens, inclusief woestijnen en poolgebieden, of, om in Suriname te blijven, ro millioen mensen op de Tafelberg, die er niet af kunnen omdat het beneden ook vol is.

Zover zal het zeker niet komen, maar het aantal alternatieven is uiterst beperkt. Alvorens tot een analyse van deze alternatieven over te gaan, lijkt het wenselijk eerst enkele aspecten van het bevolkingsprobleem in Suriname te behandelen. 
HOE ZIET DE SITUATIE IN SURINAME ERUIT?

Afgeronde getallen aanhoudend, kan de totale bevolking in I960 gesteld worden op 250.000. Het is misschien iets hoger, doch dat doet er voor dit betoog weinig toe. Wanneer de bevolkingstoename in Suriname gelijk was aan die van het gemiddelde over de laatste halve eeuw in de wereld, dan moeten wij rekenen met een verdere verdubbeling in de 40 jaar. Dat ziet er in het begin nog niet zo dramatisch uit, maar als $U$ even doorrekent, wordt het totaal spoedig benauwend.

$\begin{array}{ll}\text { In 2000: } & 500.000 \\ \text { in 2040: } & \text { I millioen } \\ \text { in 2080: } & 2 \text { millioen } \\ \text { in 2120: } & 4 \text { millioen en } \\ \text { in 2160: } & 8 \text { millioen. }\end{array}$

Maar volgens de gegevens van VAN DER KUYP, WALvis \& VAN LIER liggen de werkelijke cijfers veel hoger en moet met een geboorte-overschot van ruim $3,5 \%$ en een verdubbeling per 20 jaar worden gerekend.

Houden wij deze cijfers aan, dan zou de bevolking van Suriname in het jaar 2000 niet een half millioen, doch $\mathrm{I}$ millioen bedragen. Nog niet verontrustend, doch daarna werkt de stijging pas goed door.

$$
\begin{array}{rrc}
\text { In 2040: } & 4 \text { millioen } \\
\text { in 2080: } & 16 \text { millioen } \\
\text { in 2120: } & 64 \text { millioen en } \\
\text { (over 200 jaar) } & \text { in 2160: } & 256 \text { millioen. }
\end{array}
$$

$\mathrm{Nu}$ zullen velen zeggen: "Maar dat gebeurt natuurlijk niet," of: "200 jaar is nog zo ver in de toekomst." Wanneer de ontwikkeling van de mensheid naar eigen leven wordt afgemeten, dan lijken 200 jaar inderdaad lang, maar in de geschiedenis der mensheid is 200 jaar slechts een seconde, of om het anders uit te drukken, voor onze generatie is het probleem nog niet dramatisch, maar voor onze kleinkinderen zal het dit reeds zijn.

Op de eerste tegenwerping: "Dit gebeurt natuurlijk niet", past de wedervraag: "Waarom niet?", tenzij de mensheid zelf dit probleem in zijn volle omvang gaat onderkennen. Op zeer korte termijn heeft deze bevolkingsexplosie in Surinam echter verschillende consequenties. 
Uit de rapporten van de United Nations (p. I44) blijkt, dat in I947 de verdeling van de bevolking naar leeftijd was:

$\begin{array}{cccc} & \text { Wereld } & \text { West Europa } & \text { Latijns Amerika } \\ \text { O-15 jaar } & 36 \% & 24 \% & 40 \% \\ \text { I5-59 jaar } & 57 \% & 62 \% & 55 \% \\ \text { 6o jaar en ouder } & 7 \% & 14 \% & 5 \%\end{array}$

Volgens VAN DER KUYP waren in 1944 in Suriname deze cijfers:

$\begin{array}{cr}\text { O-I5 jaar } & 44 \% \\ \text { I5-59 jaar } & 49 \% \\ 60 \text { jaar en ouder } & 7 \%\end{array}$

Dit betekent in I 960 op een bevolking van 250.000 zielen meer dan I00.000 kinderen en weer volgens VAN DER KUYP zal dit aantal in 1970 reeds bijna 200.000 bedragen.

Een dergelijke toename geeft uiteraard grote problemen voor de opvoeding, niet alleen scholen, maar ook onderwijzend personeel. In 1955 gingen, inclusief de fröbelscholen, totaal 56.000 kinderen op school, of ruim $25 \%$ van de bevolking. Voor het schooljaar r960-196r bedraagt dit aantal reeds 63.00o en binnen 20 jaar zal het aantal schoolkinderen de 100.000 zijn gepasseerd.

Reeds nu zijn alle scholen in Suriname, zoals bijna overal in de wereld, overvol en het zal reeds een uiterst zware taak zijn om het huidige peil te handhaven. Bij verdubbeling van het totaal aantal klaslokalen binnen 20 jaar zal geen sprake kunnen zijn om zelfs maar tot enige verbetering van het peil te komen.

Opvoeding is kostbaar, zowel voor de ouders als voor de gemeenschap. Het kan, wederom volgens rapporten van de U.N. en volgens vele andere deskundigen, gesteld worden, dat grote gezinnen het uiterst moeilijk maken om de zorg en de opvoeding van de kinderen te verbeteren en de grootste belemmering vormen voor verbetering van het gezinsleven. Natuurlijk zijn er uitzonderingen en die zullen er altijd blijven. Iedereen kent voorbeelden van begaafde kinderen uit grote gezinnen, maar het gaat in dit betoog om de totale bevolking en niet om de uitzonderingen.

Gesteld, dat Suriname in staat zal zijn al deze kinderen redelijk op te voeden, dan rijst onmiddellijk de vraag: "Wat moeten deze kinderen later gaan doen?" Bij analyse blijkt het antwoord benauwend.

In I960 bedroeg het aantal mannen in Suriname beneden de 
45 jaar ongeveer Iro.000, waarvan 60.000 jongens onder de 15 jaar en 20.000 ouder dan 45 jaar. Zelfs wanneer aangenomen wordt, dat over 20 jaar een ieder, die nu ouder dan 45 jaar is, zal hebben opgehouden met werken, dan betekent dit toch, dat binnen 20 jaar werkgelegenheid zal moeten worden gevonden voor 60.000 minus $20.000=40.000$ nieuwe arbeidskrachten. En dan slaat dit nog alleen op mannen en niet op meisjes en vrouwen, mede betrokken in het arbeidsproces.

$\mathrm{Nu}$ is gelukkig 40.000 geen astronomisch getal, maar toch zal het werk creëren een uiterste krachtsinspanning van een ieder vragen. Immers, nieuwe werkgelegenheid in de landbouw, bosbouw of industrie impliceert toename landbouwareaal, nieuwe polders.

Kosten landbouw. Stel 5 HA/gezin à $f$ rooo/HA is reeds $f$ 500o.-.

Industrialisatie. Brokopondo 200 millioen Sur. guldens, werkgelegenheid smelter en aluinaardefabriek, plus alle bijkomende diensten, misschien 2000 man, of een investering van $f$ roo.000/ gezin. Kleinere industrieën zullen uiteraard veel minder vragen, doch misschien illustreren deze enkele voorbeelden, dat creëren van nieuwe werkgelegenheid voor 40.000 werkers nieuwe investeringen in Suriname zullen vereisen van vele honderden millioenen Surinaamse guldens.

De vraag zal wellicht gesteld worden of Suriname momenteel overbevolkt of onderbevolkt is. Daarop zou eerst onderzocht moeten worden: wat is overbevolkt. Een aanvaardbare definitie zou misschien zijn: een groter aantal inwoners in het land dan verenigbaar met een menswaardig bestaan. Dan blijkt het duidelijk, dat in een land als Suriname met zijn enorme, vrijwel of zelfs geheel lege ruimtes, het begrip over- of onderbevolkt voor nog een lange tijd door vele factoren bepaald zal zijn. Zou b.v. morgen een groot aantal rijke ertsvoorkomens in het binnenland worden gevonden, waardoor binnen enkele jaren een groot aantal mijnbouwmaatschappijen zich in Suriname zouden willen vestigen, dan zou men in dat geval al spoedig van onderbevolking spreken. Maar dit is een hypothetisch geval, voor Suriname gaat het om de huidige realiteit. Het is beter om in Suriname te spreken van overbevolking in de stad en onderbevolking in het binnenland, waarbij geconcludeerd kan worden, dat de bevolking van Suriname zeker nog sterk zal kunnen groeien, doch ernstige spanningen en onoplosbare problemen slechts kunnen worden voorkomen, indien de huidige bevolkingsexplosie wordt ingetoomd tot geleidelijke toename. 
Gelukkig voor Suriname is er nog ruimte, zijn er nog mogelijkheden en loopt de bevolkingstoename nog niet in de astronomische getallen. Vergeleken met landen als India, Java of wilt $\mathrm{U}$ in de buurt blijven, vele eilanden in het Caraibisch gebied als Puerto Rico, Barbados, is het probleem nog niet onoplosbaar, maar het kan dit in de naaste toekomst, ook in Suriname, worden, tenzij:

En dit 'tenzij' kan beter belicht worden in het raam van het wereldgebeuren.

Dan zou, geloof ik, allereerst gesteld kunnen worden, dat de groei van de mensheid past in het overal waarneembare streven in de natuur van het kleine naar het grote, zowel in het individu als in aantallen. Het schijnt zo te zijn, dat de natuur doorgaat met experimenteren totdat de grenzen overschreden worden en een nieuw experiment begint. In vroegere tijden, dinosaurussen en dergelijken, nu olifanten en walvissen; waarmede opnieuw de grens schijnt bereikt en misschien is de groei van de mensheid het laatste experiment. Of bij dit experiment het bestaan van de mensheid zelf op het spel wordt gezet, zal daarbij geen rol spelen; de talloze uitgestorven diersoorten en het opnieuw beginnen, zie b.v. de ontwikkeling van de zoogdieren, schijnen dit te bewijzen. Alleen de mens kan, als hij dit wil, de natuur overwinnen.

De keuze uit de middelen om een catastrofale bevolkingstoename te voorkomen, zijn beperkt en hebben allen hetzelfde doel: een redelijk evenwicht herstellen tussen geboorte- en sterftecijfer. Omhoogbrengen van de sterftecijfers door het ophouden van elke gezondheidszorg, zowel individuele als openbare en vooral preventieve gezondheidszorg zal niemand willen. Vergroting van het sterftecijfer door natuurrampen of oorlogen is gebleken geen noemenswaardige rol te spelen. Dat wereldoorlogen in verhouding minder slachtoffers vragen dan oorlogen van beperkter omvang vroeger, is het gevolg van het uitblijven van epidemieën tijdens en na de oorlog.

Een wel zeer onwaarschijnlijk alternatief lijkt emigratie naar andere planeten en sterren. Om verder grote toename van de bevolking te voorkomen zouden jaarlijks $2 \%$ van de mensheid of niet minder dan 60 millioen mensen het wereldruim ingeschoten moeten worden.

Tenslotte nog het alternatief van atoomoorlog, met totale of bijna een totale vernietiging der mensheid, een oplossing die slechts zou bewijzen, dat de mensheid onmachtig is om eigen verantwoordelijkheid voor dit probleem te willen aanvaarden. 
Het is derhalve duidelijk dat, indien de sterftecijfers niet omhoog gebracht kunnen worden, een redelijk evenwicht slechts bereikt zal kunnen worden door het omlaag brengen van het geboortecijfer.

En hiermede komt dan het delicate en moeilijke onderwerp van de geboortebeperking aan de orde, een onderwerp, waartegen vrijwel een ieder zich instinctief verzet. Een onderwerp, dat direct raakt aan nog onopgeloste problemen op het gebied van religie, physiologie, psychologie, sociologie en zelfs pharmacie. Maar indien de mens op aarde met verantwoordelijkheid is belast, dan volgt hieruit onontkoombaar, dat de mens dit probleem onder ogen zal moeten zien en geschiedt dit eenmaal, dan zal de keuze niet anders dan op geboortebeperking kunnen vallen.

Ter voorkoming van misverstand, geboortebeperking betekent geenszins het propageren van kinderloze of zeer kleine gezinnen. Immers bij een gezin van gemiddeld 3 kinderen zal de totale mensheid ongeveer op peil blijven of zeer weinig toenemen. Volledige egalisatie lijkt uit den boze, maar indien op korte termijn alleen maar een halt zou kunnen worden toegeroepen aan de zeer grote gezinnen, dan zou de bevolkingsexplosie al aanmerkelijk in kracht afnemen, want het gaat juist om de grote getallen.

Het standpunt van de verschillende godsdiensten t.o.v. dit probleem loopt uiteen. Wereldgodsdiensten als Islam, Hindu en Boeddhisme geven geen zwart-wit uitspraak en dit betekent in feite, dat hier geen onoverkomelijke hinderpalen bestaan indien het besef van de dwingende noodzaak doorbreekt.

Van het Christendom heeft het Protestantse deel, bij monde van de Wereldraad der Kerken, zich in meerderheid reeds openlijk uitgesproken voor geboortebeperking, de R.K. Kerk nog niet, doch het lijkt wel duidelijk, dat aanpassing in de naaste toekomst zal geschieden. Bewijzen zijn hiertoe te over, al zal dit van Rooms-Katholieke zijde nog niet openlijk worden toegegeven.

Eventuele andere invloeden op de mens zelf door geboortebeperking worden thans in vele landen bestudeerd, al ontbreekt hierbij nog algemene leiding. Het probleem is ook teveel verweven met nationale gevoeligheden dan dat lichamen als de Verenigde Naties of the World Health Organisation iets anders kunnen doen dan helpen en adviseren waar dit gevraagd wordt.

Ook bij een beschouwing over de houding van de mensheid tegenover dit probleem over de gehele wereld blijkt deze zeer 
verdeeld te zijn. In West Europa is vrijwel een evenwicht bereikt, sommige landen als Nederland zijn daar om speciale redenen nog niet aan toe; in de meeste andere landen is dit reeds vrijwel het geval.

Een ander voorbeeld van gedeeltelijk hersteld evenwicht is Japan, waar het aantal geboortes van 35/000 voor de oorlog, thans is teruggebracht tot onder de 20/000. Aanvankelijk door abortus op grote schaal, thans steeds meer door preventieve middelen. In het algemeen hebben eilandbewoners meer begrip voor het probleem van overbevolking dan die van het vasteland. En zo is het niet te verwonderen, dat Japan haar inwonersgetal van 1600-1850 constant wist te houden en nu opnieuw bewust probeert dit te doen.

Een ander voorbeeld, waar de Regering bewust bevolkingstoename tracht tegen te gaan is India. Uit talloze studies en statistieken is duidelijk gebleken, dat geen land zichzelf kan industrialiseren, het levenspeil van haar bevolking kan opvoeren, indien gelijktijdig deze bevolking op een dergelijke wijze toeneemt, dat alle beschikbare middelen nodig zijn om de toename van de bevolking in leven te houden, niet eens redelijk te voeden, doch in net voldoende mate om niet een ieder van honger te laten omkomen. Er zijn momenteel maar een paar landen over in de wereld, waar enige toename van de bevolking nog verenigbaar is met verhoging van de welvaart. De voornaamsten zijn de Verenigde Staten, Canada, Rusland, Australië, Nieuw-Zeeland en ook deze landen zullen snel het punt bereikt hebben, waar dit niet meer het geval zal zijn.

Het probleem kan ook ideëel worden gesteld. Wat verdient de voorkeur, een zo groot mogelijk aantal mensen op de aarde in uiterst kommervolle omstandigheden, die net niet van honger dood gaan, ò voor ieder mens op aarde een menswaardig bestaan?

Tenslotte nog een ander aspect. Grote bevolkingstoename, opeenhopingen in millioenensteden, brengt onverbiddelijk mede het verloren gaan van democratische waarden. In een millioenenstad kan de eenling geen enkele persoonlijke invloed op het stadsbestuur uitoefenen, ook de gemeenteraad kan dit niet meer, en het gevolg is, dat het bestuur steeds meer overgelaten wordt aan ambtenaren. In een wereldstad is het zich volledig ontplooien van de mens in al zijn persoonlijke mogelijkheden al vrijwel on- 
mogelijk geworden. De vraag kan ook gesteld worden: wil de mensheid dit eigenlijk: ontplooien van eigen persoonlijkheid vereist eigen inspanning, het is zoveel gemakkelijker om het maar aan anderen over te laten. Massavermaken inplaats van individuele ontspanning, geleefd te worden inplaats van zelf te leven. Zonder 'challenge', zonder eigen inspanning, ook geen waardering voor het verkregene met als mogelijk gevolg een afsterven van de capaciteit tot ontplooiing. Hoe voller en gecompliceerder de wereld wordt, hoe moeilijker het voor het individu wordt het eigene te vinden en te ontwikkelen.

Het toekomstbeeld voor de mensheid is weinig opwekkend en er is maar heel weinig tijd meer om tot een oplossing te geraken. De huidige ontwikkeling is zo snel, dat het hoogstens nog aan een of twee generaties gegeven zal zijn, in redelijkheid tot een menswaardige oplossing te komen. Gehoopt kan slechts worden dat deze generaties de daarvoor benodigde wijsheid en het inzicht zullen opbrengen.

\section{SUMMARY}

SURINAM AND THE POPULATION PROBLEM

It is a well-known fact that the fast population growth must be regarded as one of the most explosive problems of our present-day world. After showing the gravity of this problem the author concentrates on Surinam with her small population.

Characterizing the situation in Surinam as overpopulation in Paramaribo and underpopulation in the interior, the author considers some educational, hygienic and employment problems, which are caused by the rapidly growing population of the country. 